DOI: http://dx.doi.org/10.24093/awejtls/vol1no1.4

\title{
Fansubbing in the Arab World: Modus Operandi and Prospects
}

\author{
Hani Abdulla Eldalees \\ College of Humanities and Social Sciences \\ Hamad Bin Khalifa University, Doha- Qatar
}

Amer Al-Adwan

College of Humanities and Social Sciences, Hamad Bin Khalifa University, Doha- Qatar

\section{Rashid Yahiaoui}

College of Humanities and Social Sciences, Hamad Bin Khalifa University, Doha- Qatar

\begin{abstract}
This paper analyzes the subtitles generated by Arab amateur subtitlers, who are commonly known as fansubbers. The study is based on scrutinizing two copies of the film The Wolf of Wall Street which has been subtitled by fans in two different Arab countries, Jordan and Lebanon. The study is designed to analyze the Arabic subtitles generated in each DVD to understand how subtitlers from each country deal with different problematic issues and distasteful topics in the film, including utterances related to sexuality, swear words andreferences to embarrassing bodily functions. The study applies the model of euphemisation in subtitling proposed by AlAdwan(2015) which has beenderived primarily from two existing models of euphemisation presented by Williams (1975) and Warren (1992). The applied model has managed to address the majority of the problematic instances and has also identified strategies adopted to tackle them in the Arabic subtitles. However, the model has not been able to account for other instances found in both DVDs where subtitlers also used dysphemism as a translation strategy. The analysis reveals that fansubbers do not only use euphemism but also dysphemism in their Arabic subtitles when translating certain problematic utterances.

Keywords: Arabiclanguage, dysphemism, euphemism, fansubbing, taboo, translation strategies

Cite as: Eldalees, H.A. Al-Adwan, A. \& Yahiaoui, R. (2017). Fansubbing in the Arab World: Modus Operandi and Prospects. Arab World English Journal for Translation \& Literary Studies, 1(1). DOI: http://dx.doi.org/10.24093/awejtls/vol1no1.4
\end{abstract}

